dr hab. inz. Marian Medwid, prof. nadzw.

mgr inz.Tomasz Nowaczyk

mgr inz. Wojciech Jakuszko

Instytut Pojazdów Szynowych , TABOR”

\title{
Technologia przeładunku poziomego na przykładzie modułowego systemu transportu kombinowanego
}

\begin{abstract}
$W$ artykule przedstawiono innowacyjne rozwiqzanie „,Modulowy system transportu kombinowanego", stużacy do przewozu naczep drogowych. Zaprezentowano podstawowe sktadowe struktury systemu. Opisano etapy formowania sktadu pociqgu $w$ technologii przeładunku poziomego oraz zwiqzane z tym rodzajem przeładunku zalety. Porównano system do istniejacych technologii transportu kombinowanego. Prezentowany projekt jest wynikiem prac badawczych prowadzonych $w$ ramach realizacji projektu rozwojowego $\mathrm{nr}$ R10-0065-10 „, System transportu naczep drogowych na wózkach kolejowych w kombinowanym ruchu kolejowo-drogowym".
\end{abstract}

\section{WSTĘP}

Transport kombinowany ze względu na rodzaj przewożonej jednostki ładunkowej, co również ma wpływ na rodzaj stosowanego sposobu przeładunku, można podzielić na: przewóz kontenerów, nadwozi wymiennych, naczep, całych zestawów drogowych. Podział przedstawia rysunek 1.

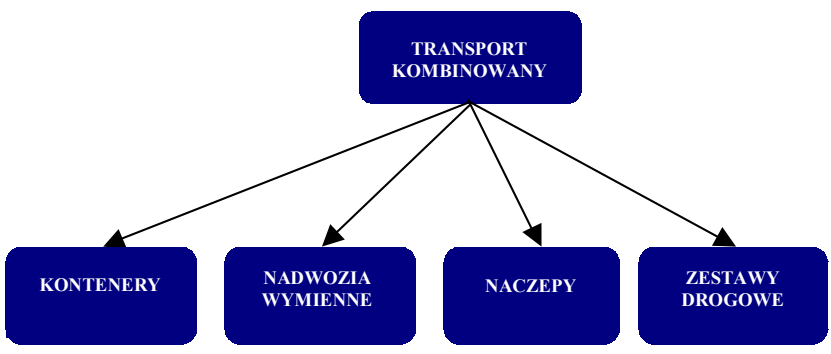

Rys.1. Podział transportu kombinowanego ze względu na stosowane jednostki intermodalne [1]

W Transporcie kombinowanym szynowodrogowym można wyróżnić dwa podstawowe sposoby przeładunku intermodalnej jednostki ładunkowej pomiędzy środkiem transportu drogowego i kolejowego:

1. Przeładunek pionowy, tzw. lift on-lift off (lo-lo).

2. Przeładunek poziomy, tzw. roll on-roll off (ro-ro).

Przeładunek pionowy wymaga wykorzystania suwnic oraz specjalistycznych wozów, które unoszą jednostkę ładunkową w celu za- lub wyładunku, stąd nazwa pionowy. Przeładunek poziomy natomiast odbywa się przy wykorzystaniu kół drogowych pojazdu, bez unoszenia jednostki ładunkowej. W transporcie „towarzyszącym” (rys.2a), inaczej ruchoma droga (niem. Ro-La czyli Rollende Landstrasse, ang. rolling motorway) kompletny zestaw złożony z ciagnika siodłowego oraz naczepy siodłowej wjeżdża sam na spe- cjalny wagon-platformę, jest to przeładunek typu roro.

W transporcie „nietowarzyszącym” (rys.2b), inaczej „na barana” (niem. Huckepack, ang. piggyback), który polega na transportowaniu koleją samych jednostek ładunkowych bez ciąników siodłowych, występuja obydwa wymienione rodzaje technologii przeładunku (ro-ro oraz lo-lo). Prezentowany poniżej system modułowy stanowi innowacyjne rozwiazzanie transportu szynowo-drogowego, które służy do przewożenia naczep drogowych a jego przeładunek odbywa się w technologii poziomej „ro-ro”.

\section{STRUKTURA MODUŁOWEGO SYSTEMU}

Innowacyjny, modułowy system transportu kombinowanego przedstawia rysunek 3 . Moduł systemu sformułowany jest $\mathrm{z}$ dwóch jednakowych zespołów. Każdy z nich składa się z odpowiednio przystosowanej standardowej naczepy drogowej oraz platformy kolejowej złożonej $\mathrm{z}$ dwóch rozłącznych układów biegowych - przedniego i tylnego. System ten jest przeznaczony do transportu naczep wyposażonych w hamulce tarczowe o rozstawie opon 2040-2100mm. Terminal przeładunkowy natomiast wymaga jedynie tak zwanej „drogi bimodalnej” (poziom jezdni drogowej zrównany jest z wysokością górnej powierzchni główki szyny) oraz odsuwnych pomostów najazdowych umożliwiających najazd naczep na wysokość półek tylnych układów biegowych platform kolejowych. Tak prosta aranżacja terminalu sprawia, że można do systemu włączyć praktycznie dowolne istniejące już bocznice kolejowe. 
a)

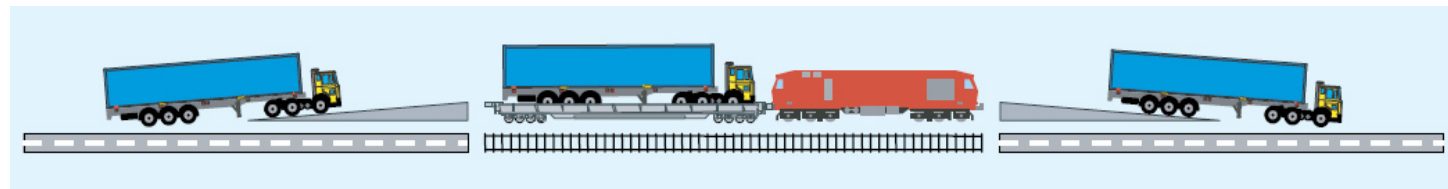

b)

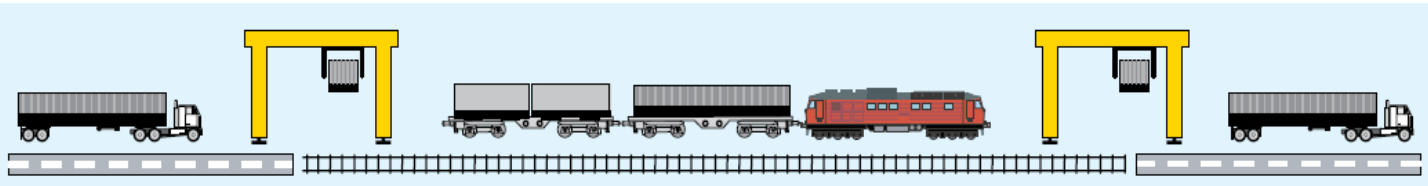

Rys.2. Transport intermodalny a) towarzyszący, b) nietowarzyszący [5]

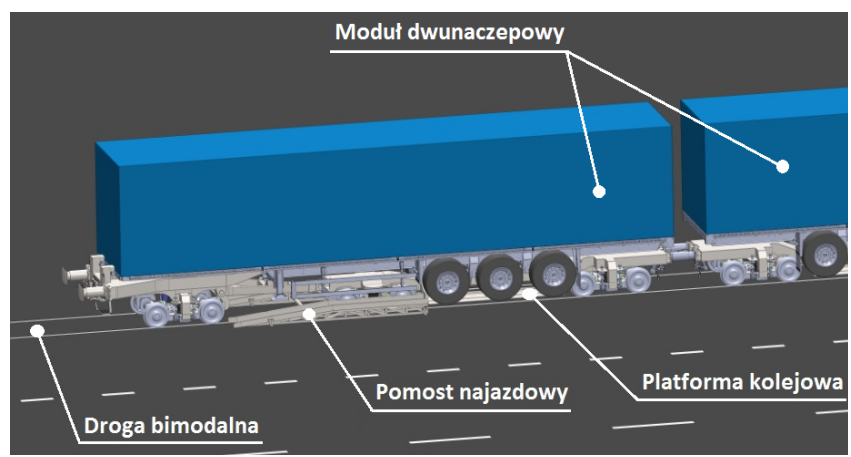

Rys.3. Moduł systemu transportu kombinowanego [opracowanie własne]

Przedni układ biegowy przedstawiony na rysunku 4 składa się z specjalnego obniżonego wózka dwuosiowego 1 o średnicy kół ø580, posadowionego na nim adaptera 2 stanowiącego oparcie i mocowanie dla naczepy drogowej oraz cięła stanowiącego część złączną układów biegowych. Zespół ten wyposażony jest $\mathrm{w}$ typowe urządzenie pociagowo-zderzne, służące do łączenia kolejnych modułów dwunaczepowych, oraz modułów z lokomotywą lub składem pociagu.

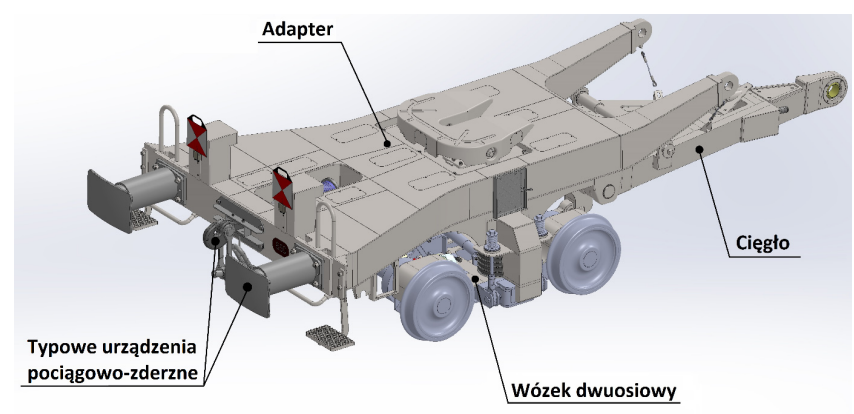

Rys.4. Przedni układ biegowy [opracowanie własne]

Tylny układ biegowy (rys.5), poprzez który platformy kolejowe połączone są ze sobą krótkospiętym urządzeniem pociagowo-zderznym, złożony jest $\mathrm{z}$ dwóch jednakowych wózków jak w przedniej strukturze oraz posadowionej na nich ramie stanowiącej oparcie dla naczepy poprzez koła drogowe. Z przedniej strony znajduje się zamek cięgła łączącego układy biegowe.

Przednia i tylna część biegowa stanowią punkty podparcia naczepy w tych samych miejscach jak pod- czas jazdy po drodze kołowej, zatem warunki obciążenia pionowego ramy naczepy $\mathrm{w}$ uformowaniu drogowym i kolejowym pozostają bez zmian. Wzdłużne siły pociągowe i różnica poziomu wysokości urządzeń pociagowo-zderznych $\mathrm{w}$ przednim i tylnym układzie platformy kolejowej wymuszają potrzebę wzmocnienia konstrukcji. Przyrost masy naczepy jest jednak znacznie mniejszy jak w przypadku naczepy bimodalnej i wynosi on $900 \mathrm{~kg}$.

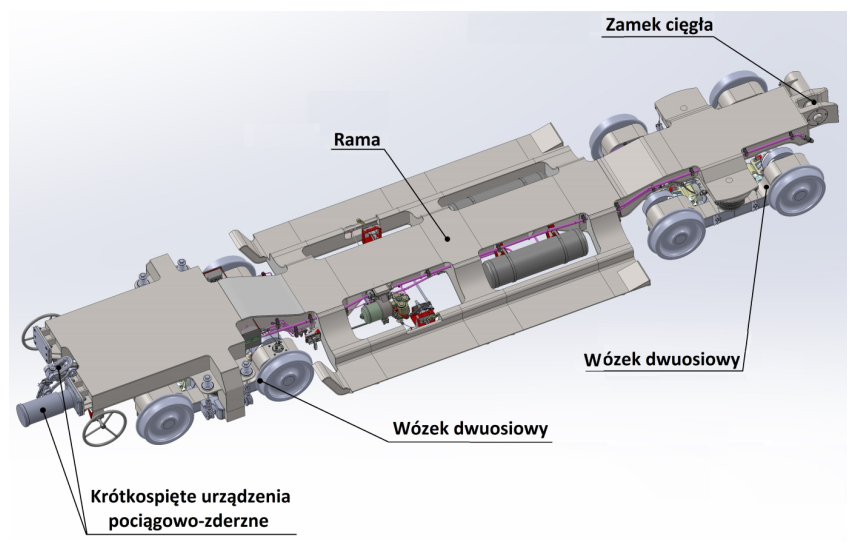

Rys.5. Tylny układ biegowy [opracowanie własne]

\section{ETAPY ZAŁADUNKU W TECHNOLOGII „RO- RO”}

Załadunek poziomy naczepy drogowej na platformę kolejową odbywa się na płaskim terminalu, gdzie poziom jezdni zrównany jest $\mathrm{z}$ poziomem główki szyny toru kolejowego. Rysunek 6 przedstawia poszczególne fazy formowania pojedynczego modułu systemu transportu kombinowanego w technologii „,ro-ro”.

Etapy przeładunku przebiegają następująco:

\section{Faza I.}

Po dostawieniu i zablokowaniu rozsuwnych pomostów najazdowych ciagnik siodłowy wprowadza naczepe na półki platformy kolejowej na wysokość $270 \mathrm{~mm}$ powyżej powierzchni główki szyny. Istotnym ograniczeniem w tym etapie jest przejechanie naczepy ponad wózkiem środkowym platformy i uniknięcie kolizji pomiędzy kołami kolejowymi wózka środkowego a znajdującym się ponad podczas najazdu pneumatyczno-wahaczowym zawieszeniem naczepy. Ze 

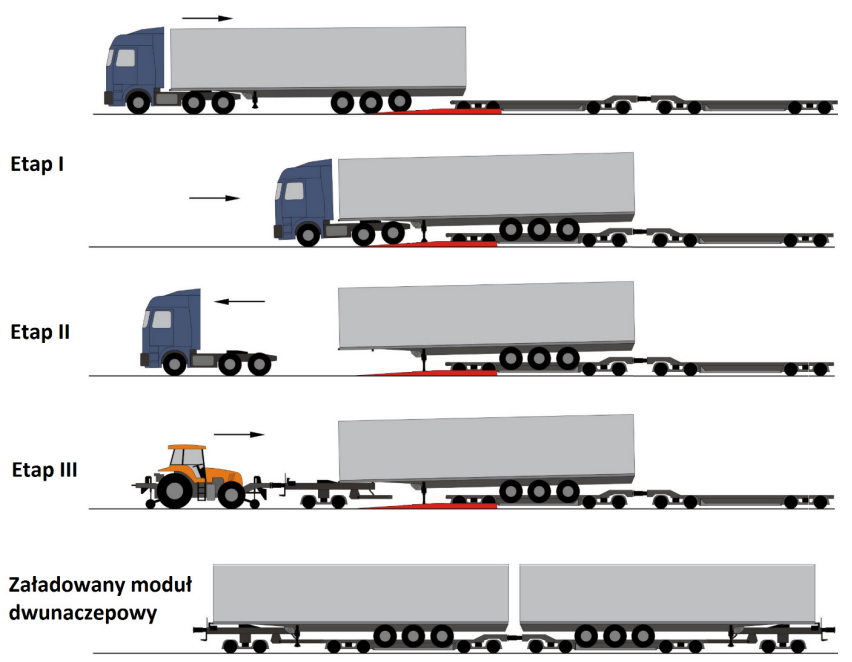

Rys.6. Etapy załadunku w systemie modułowym [opracowanie własne]

względu na hamulce tarczowe znajdujące się wewnątrz kół drogowych nie ma również kolizji pomiędzy zestawem kołowym naczepy a kołami kolejowymi.

1. Faza II.

Po wtoczeniu naczepy na wysokość półek platformy tylnego układu biegowego do momentu oparcia tylnych kół o blokadę tylną platformy następuje opróżnienie miechów nośnych naczepy celem obniżenia wysokości w składzie kolejowym oraz oparcie na nogach podporowych i wypięcie ciagnika siodłowego spod sworznia zaczepowego typu „Jost”.

2. Faza III.

Pod ustawiona naczepe na platformie tylnego układu następuje wtoczenie przedniej części biegowej przy pomocy pojazdu poruszającego się po torach lub na kołach drogowych po bimodalnej jezdni zrównanej z poziomem główki szyny. Po wtoczeniu wózka następuje równoczesne zaryglowanie adaptera $\mathrm{w}$ naczepie drogowej oraz połączenie przedniej i tylnej części biegowej poprzez cięgło podwieszone na adapterze przednim. Na końcu zostają podniesione nogi podporowe naczepy.
Drugi zespół modułu zostaje połączony analogicznie i może odbywać się równocześnie, w ten sposób otrzymujemy sformowany moduł składający się z 2 naczep drogowych oraz dwóch platform kolejowych połączonych na stałe krótkospiętym urządzeniem pociagowo-zderznym. Rozładunek modułu przebiega w odwrotnej kolejności jak przedstawiony załadunek $\mathrm{w}$ fazie I-III. W ten sposób połączone moduły dwunaczepowe można łączyć między sobą za pomocą typowych urządzeń pociągowo-zderznych. Formowanie modułów może odbywać jednocześnie w sposób szeregowy lub szeregowo-równoległy (rys.7a,b), znacznie skracając czas załadunku w zależności od liczby pojazdów manewrowych wtaczających przednie układy biegowe.
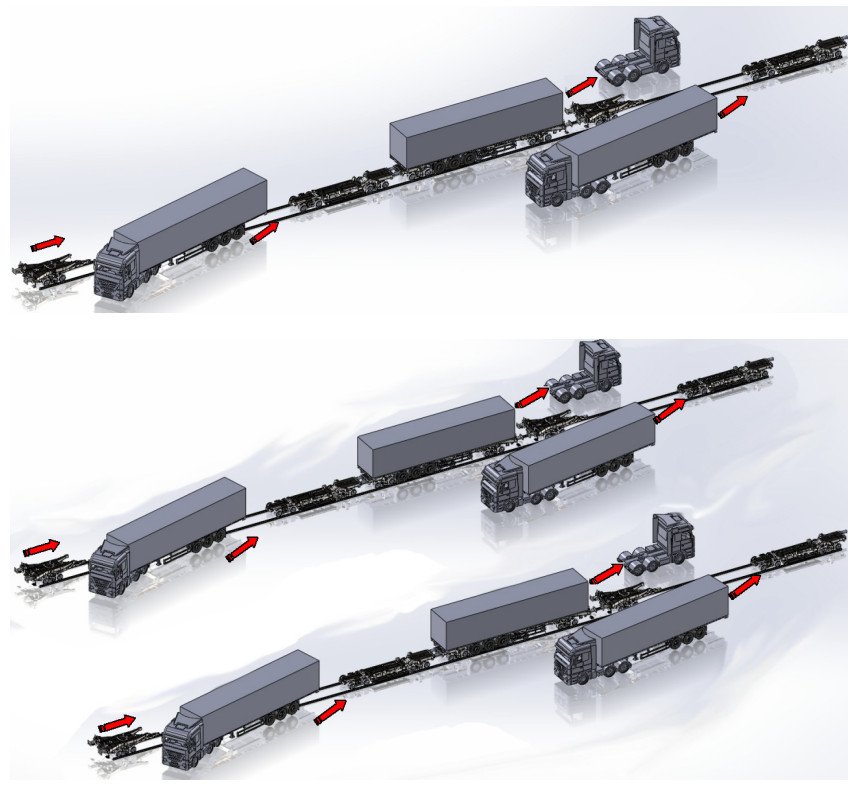

Rys.7. Formowanie modułów a) sposób szeregowy, b) sposób szeregowo-równoległy [opracowanie własne]

Dużą zaletą przeładunku poziomego w modułowym systemie transportu kombinowanego jest możliwość zastosowania zelektryfikowanych terminali, gdyż sieć trakcyjna nie stanowi przeszkody podczas za- i wyładunku. Załadunek naczepy na tle normalnej wysokości przewodu trakcyjnego pokazuje rysunek 8 .

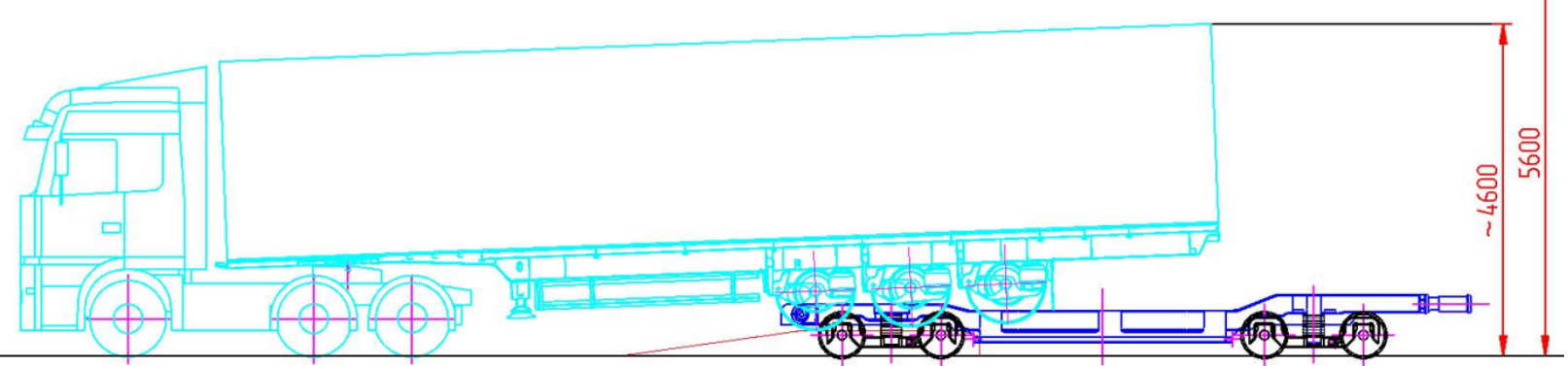

Rys.8. Załadunek naczepy pod siecią trakcyjną [opracowanie własne] 


\section{PODSUMOWANIE}

System transportu modułowego łączy w sobie wiele zalet innych systemów tej technologii a zarazem wyklucza ich wady i istniejące ograniczenia. Najważniejszą zaletą systemu może być stosunkowo niski koszt produkcji oraz eksploatacji. System opiera się na prostych oraz niedrogich rozwiązaniach, nie wymagających częstej i kosztownej obsługi. Koszt wyposażenia i przygotowania terminalu przeładunkowego również stanowi dużą konkurencyjność wobec innych systemów, do procesu formowania składu wymagana jest jedynie „droga bimodalna”, pomosty najazdowe oraz przynajmniej jeden ciagnik wtaczający przednie układy biegowe. Przykładowy ciagnik szynowodrogowy opatentowany przez konstruktorów Instytutu Pojazdów Szynowych „TABOR” w Poznaniu jest nawet kilkakrotnie tańszy w stosunku do lokomotywy manewrowej a może on służyć poza wtaczaniem przednich układów biegowych także do łączenia modułów w skład pociagu. Ciagnik może poruszać się zarówno po drodze asfaltowej jak i torach kolejowych, co zapewnia elastyczność i szybkość wykonywanych operacji. Załadunek może odbywać się zarówno na terminalach niezelektryfikowanych jak również wyposażonych w sieć trakcyjną. Umożliwia to przedstawiona w niniejszym artykule prosta operacja przeładunku modułów w technologii „,ro-ro”. Dla terminali zelektryfikowanych kolejną zaletą jest możliwość bezpośredniego podpięcia pod skład pociagu elektrycznej lokomotywy szlakowej, bez potrzeby wcześniejszego wykorzystywania spalinowej lokomotywy manewrowej. Pomniejszona średnica kół umożliwia załadunek $\mathrm{w}$ technologii ro-ro $\mathrm{w}$ prosty sposób poprzez przejazd naczepy ponad wózkiem środkowym tylnego układu biegowego a zarazem sprawia, że system modułowy mieści się w skrajni kolejowej UIC GB1. Średnica kół jest jednak większa jak w przypadku systemu Ro-La, co w porównaniu do tego systemu poprawia warunki bezpieczeństwa podczas jazdy oraz wydłuża okresy pomiędzy wymianą zużytych kół. Podsumowując system ten umożliwia stosunkowo tanią obsługę a zarazem w zależności od liczby pojazdów manewrowych na terminalu przeładunkowym krótki czas trwania przeładunku.

\section{BIBLIOGRAFIA}

1. Nowaczyk T., Wybrane charakterystyki transportu intermodalnego (szynowo-drogowego), Praca magisterska NR TR-M/S-11/2009.

2. Medwid M., Cichy R., Nowaczyk T., Model strukturalny systemu transportu naczep drogowych na wózkach kolejowych w ruchu kombinowanym kolejowo-drogowym, Pojazdy Szynowe nr 2/2011, Wydawnictwo IPS „,Tabor" Poznań.

3. Madej J., Medwid M., Cichy R., Jakuszko W., Nowaczyk T., Modulowy system transportu naczep siodtowych na wózkach kolejowych $w$ ruchu kombinowanym kolejowo-drogowym, XX Międzynarodowa Konferencja Naukowa „Pojazdy Szynowe 2012”- Poznań.

4. Medwid M., Cichy R., Ciagnik szynowo-drogowy o zwiększonej wytrzymatości mechanicznej na działanie sit wzdluznych, Pojazdy Szynowe nr 1/2010, Wydawnictwo IPS ,, Tabor" Poznań.

5. Statistics 2007, Union Internationale des societes de transport combine Rail-Route.

6. PN-69/K-02057, Skrajnie budowli. 